\title{
Patterns of the Teaching and Learning Cycle of GBA by EFL Teachers in Indonesia
}

\section{Suharyadi ${ }^{1 \times}$ Yazid Basthomi ${ }^{2}$}

Universitas Negeri Malang, Indonesia.

Email:suharyadi.fs@um.ac.id Tel: +6281385030506

`Email: ybasthomi@um.ac.id Tel:+6281231682788

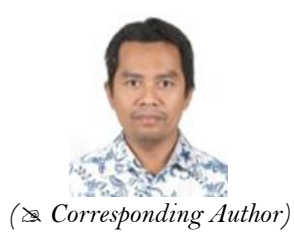

( Corresponding Author)

\begin{abstract}
This article purposes to tease out the EFL teachers' patterns in implementing the stages of teaching and learning using GBA in the Indonesian context. The participants involved in the study were 15 English teachers from seven state senior high schools in Kota Malang Indonesia. The data were collected through interviews and observations. Fieldnotes were also made to record the relevant data. The observations of each teacher were carried out five times to attain sufficient data for the analysis. The writers observed the classes recommended by the teachers, sitting down in the back row and observing the activities done by teachers and students. They also put a tick (v) to indicate the presence of activities as listed in the checklist. If the teachers and students did activities which were absent in the checklist, the writers made fieldnotes to record them for supplementary purposes. The data were analysed descriptively based on the descriptors in the checklists. The analysed data showed that none of the English teachers fully employed the four stages of GBA (BKoF, MoT, JCoT, and ICoT) in teaching. Instead, they also applied the stages of GBA with the following patterns: BKoF-MoT-JCoT; BKoF-JCoT; BKoF-MoT; BKoF-MoT-ICoT; and BKoF-ICoT.
\end{abstract}

Keywords: Patterns, EFL, Teachers, Stages, GBA, Indonesia.

Citation | Suharyadi; Yazid Basthomi (2020). Patterns of the Teaching and Learning Cycle of GBA by EFL Teachers in Indonesia. Journal of Education and e-Learning Research, 7(1): 3441 .

History:

Received: 4 November 2019

Revised: 6 December 2019

Accepted: 9 January 2020

Published: 19 February 2020

Licensed: This work is licensed under a Creative Commons Attribution 3.0 License (cc)

Publisher: Asian Online Journal Publishing Group
Acknowledgement: Both authors contributed to the conception and design of the study.

Funding: This study received no specific financial support

Funding: This study received no specific financial support.
Competing Interests: The authors declare that they have no conflict of interests.

Transparency: The authors confirm that the manuscript is an honest, accurate, and transparent account of the study was reported; that no vital features of the study have been omitted; and that any discrepancies from the study as planned have been explained.

Ethical: This study follows all ethical practices during writing.

\section{Contents}

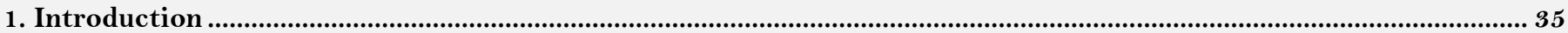

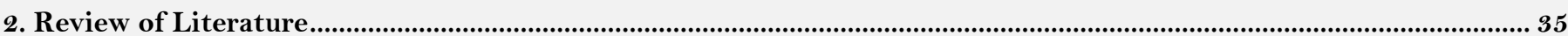

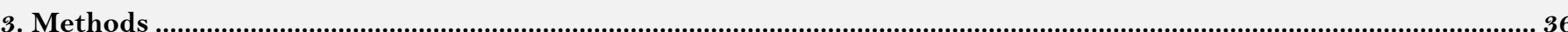

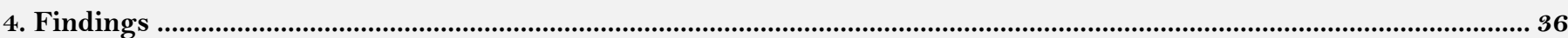

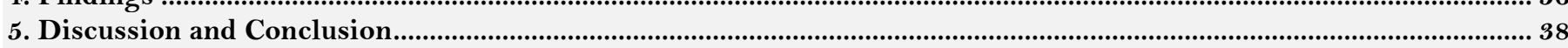

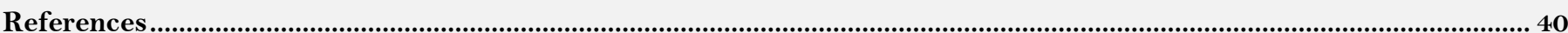




\section{Contribution of this paper to the literature}

This study contributes to addressing the gap between the theory and practice of Genre-Based Approach, particularly in the implementation of the teaching and learning cycle in the EFL context by attending to that of Indonesia.

\section{Introduction}

Genre-Based Approach (GBA) has been widely used in the global context such as Australia, Hong Kong, Singapore, Indonesia, Brazil, Chile, Sweden, Denmark and some parts of the USA (Derewianka, 2012; Moore and Schleppegrell, 2014; Emilia and Hamied, 2015; Wu, 2016; Graves and Garton, 2017; Mbau and Sugeng, 2019) and typically found in monolingual education such as for second language or foreign language (Lorenzo, 2013). Within this wider practice of GBA, the use of cycles in teaching is popular. The cycles are called in different terms: a genre curriculum cycle (Callaghan and Knapp, 1989) a wheel model of a teaching and learning cycle (Hammond et al., 1992) or the teaching and learning cycle (TLC) (Caplan and Farling, 2016; Hermansson et al., 2019). The cycles are usually presented in the form of procedures or stages with which a teacher can facilitate students to understand and produce texts. These stages help learners read and write texts (De Oliveira and Lan, 2014) and familiarize students with direct and systematic orders of different texts for writing skills (Ahn, 2012; Ueasiriphan and Tangkiengsirisin, 2019). Furthermore, the cycles are incorporated as a part of teaching strategies aiming at catering for teachers with not only a set of steps to organize the instruction, but also efforts to scaffold students to grasp and come to terms with different texts (Macken-Horarik, 2002).

Relevant research has confirmed the benefits of the cycles in teaching. Rothery (1996) has mentioned that most Australian teachers agree to use the cycles as "strategies for planning, teaching and assessment" as they become more productive working with students in language learning. Kongpetch (2006) also adds that the use of cycles encourages students to think, plan, and work with a text. However, these studies seem to provide less comprehensive accounts as to how teachers apply the cycles in teaching. There is no explicit information either about which model of cycles was adopted when teachers conducted the teaching including the typical activities in each stage. It also gives an impression that the research on the practice of the cycles was mainly undertaken in the L1 and L2, not EFL. It is widely known that English, in the EFL context, is a subject taught in high schools. It is not spoken nor used in daily communication. The exploration of cycles in this context will enrich the body of the knowledge of GBA, for this will take into account EFL context thus far overlooked.

Other relevant studies have also been conducted both in ESL and EFL settings, for instance, Ahn (2012); Carstens (2009); Chen and Su (2012); Emilia (2005); Firkins et al. (2007); Hyon (2001); Kongpetch (2006); MackenHorarik (2002); Myskow and Gordon (2009); Paltridge (2004); Pujianto et al. (2014); Rothery (1996); Trong (2011); Ueasiriphan and Tangkiengsirisin (2019); Xu (2005) and Yigitoglu and Reichelt (2014). Yet, the existing research was restricted to support the teaching of one language skill only, namely writing. This gives an impression that these studies deployed similar research designs and participants which may result in similar findings. That is why, the research on GBA needs to be expanded into other relevant areas such as speaking, listening, reading and grammar so that teachers can have wider perspectives and models of GBA application in different settings. The present study is an attempt to address this issue. Furthermore, the use of the cycle in those studies is typically found as a model in research, not in teaching. For example, Firkins et al. (2007) utilized the cycle comprising three stages: Modelling a text, Joint construction of a text, and Independent construction of a text to improve low proficiency EFL students' writing. Similarly, Wu and Dong (2009) also applied GBA in their study about writing in three stages: involving modelling the generic structure of the model text; involving the joint efforts of a teacher and students to work out another text with the same genre; and involving students' individual work and the teacher and learners editing. In addition, Trong (2011) also conducted a study on teaching writing through genrebased approach at Ho Chi Minh City University of Finance-Marketing, Vietnam in three phases (modelling of a text, joint-negotiation of text, and independent construction of text). Furthermore, Ahn (2012) utilized the three stages of GBA in teaching writing to native speakers and non-native of English. This reflects that the cycles are more prominent in research rather than in teaching. Therefore, extension of the application of the stages for pedagogic purposes is warranted.

\section{Review of Literature}

This part discusses the models of GBA as well as the activities in teaching.

\subsection{The GBA Models of Teaching}

Since this study aims at investigating how the EFL teachers implement the stages of GBA in the Indonesian context, the information about the cycles developed by several experts are incorporated. So far, there have been four models used in language teaching based on GBA. Callaghan and Knapp (1989) developed a model comprising three phases: modelling, joint negotiation of text, and independent construction of text. Murray and Zammit (1992) also introduced a model which contains four stages: negotiating field, deconstruction, joint construction, and independent construction of text. Similarly, Rothery (1996) arranged the teaching within three stages: deconstruction, joint construction, and independent construction. Hammond et al. (1992) proposed four stages in the GBA instruction: building knowledge of the field (BKoF), modelling of text (MoT), joint construction of text (JCoT), and independent construction of text (ICoT).

In the Indonesian context, however, the model proposed by Hammond et al. (1992) with four stages is more common. There is neither specific account nor empirical reason why this model is on the rise. To the best of our knowledge through our involvement in training, the trainers suggested that teachers apply it in teaching without due explanation. The result of the literature review also indicates that none of the existing research has provided the rationale of using the model. It is, therefore, important to carry out and document the application of this model in English language teaching. 


\subsection{The Activities in the GBA Models}

This study is also believed to have the potential to equip teachers with hands-on knowledge about the stages and activities to be included in their teaching. This is in line with the proliferating teaching approach in Indonesia, that is, scientific approach. The activities are elaborated based on building knowledge of the field (BKoF), modelling of text (MoT), joint construction of text (JCoT), and independent construction of text (ICoT).

In BKoF, both teachers and students together discuss the background of the text to learn and share their experiences to deal with it: context of culture, common setting of the text, and benefits of the text (Chaisiri, 2010; Mingsakoon and Srinon, 2018; Hermansson et al., 2019). According to Yan (2005) and Emilia (2008) BKoF familiarizes students with different texts and their structural features before they start their learning, particularly writing. In the second step, MoT, teachers provide examples of texts for students to analyse in terms of the social function, generic structures, and linguistics features. According to Hyland (2007) modelling aims at exposing students with the details of the text to learn. Thus, teachers need to have adequate stock of texts to be modelled (Emilia, 2008; Pujianto et al., 2014). Joint construction, the third phase, deals with the collaboration between teachers and students and between students and students to produce the intended text. In relation to this, Pujianto et al. (2014) and Yan (2005) suggest that JCoT can be done in groups (students) and or students partnered by the teacher to accomplish one model or draft of text. After working in groups, students are asked to work independently. Hence, the stage of independent construction of text is crucial to train students to start working on their own by making use of what they have learned in the previous stages. In this phase, teachers' inference is gradually reduced (Hyland, 2007).

\section{Methods}

\subsection{Participants}

The participants involved in the study were 15 English teachers from seven state senior high schools in Kota Malang Indonesia. The teachers were selected based on the following considerations. First, they started teaching English at least in the year of 2004/2005 or 2006/2007. The year 2004/2005 was deemed as the first time of including GBA in English language teaching in Indonesian classrooms. In 2006/2007, the curriculum was revised to be the school based curriculum (KTSP), yet GBA remained unchanged. Second, the participants should have graduated from an English department with an undergraduate diploma as a minimum requirement of the teachers' qualifications. Third, they taught English in state senior high schools. Fourth, they should be tenured and certified English teachers as they are officially responsible for students' learning and usually pointed or assigned by the schools to join local, regional, national, or international workshops. In addition, they have officially been professional in the sense that they have been certified nationally. Fifth, they should have an experience of joining workshops, conferences, seminars, or training on English language teaching and GBA to ensure that they have come to terms with GBA.

\subsection{Instruments}

The instruments used in the current study included interviews, observation checklists and field notes. The interviews were focused on teachers' teaching experience, the year of starting teaching, and the involvement in training. The observation checklist consisted of several variables and descriptors concerning what and how the teachers should implement GBA in the classroom using the cycles. In this context, the variables to observe were divided into four stages of teaching, namely building knowledge of the field, modelling of the text, joint construction of the text, and independent construction of the text (Hammond et al., 1992). In each stage, specific descriptors were elaborated concerning what and how teachers taught students based on GBA. These descriptors were adapted from various sources such as English teachers' lesson plans accessed from the internet and a book on GBA by Emilia (2011). Field notes were also incorporated in the data collection and contrived to complete the information that was not duly covered through observations.

\subsection{Data Collection}

In collecting the data from the interviews, we recorded the information concerning the teachers' teaching experience, the year of starting teaching, and the involvement in the training. For the observations, we observed each teacher for five times, so that the intended data were sufficient for the analysis. We observed the classes as recommended by the teachers. We sat down in the back row observing the activities done by teachers and students. We also put a tick (v) to indicate the presence of activities as listed on the checklist. If the teachers and students did activities which were absent from the checklist, the writers made fieldnotes to record them for supplementary purposes.

\subsection{Data Analysis}

The gathered data were analysed qualitatively. The main data obtained from observations were described narratively based on stages and descriptors listed on the checklists. These descriptions reflected whether teachers had really implemented GBA or not in the classrooms. From this activity, how the teachers implemented the stages of GBA in teaching could finally be concluded. The information about the teachers' teaching performance was also supported by the results of interviews and fieldnotes.

\section{Findings}

The findings of this study deal with EFL teachers' patterns in implementing the stages of GBA as suggested by Hammond et al. (1992) building knowledge of the field (BKoF), modelling of text (MoT), joint construction of text (JCoT), and independent construction of text (ICoT) as well as the activities in the teaching of English as a subject in the school.

The analysis indicates that English teachers from different schools deployed the stages of GBA in five patterns: (1) BKoF-MoT-JCoT; (2) BKoF-MoT; (3) BKoF-JCoT; (4) BKoF-MoT-ICoT; and (5) BKoF-ICoT. Of those 
patterns, none of the teachers employed full stages. Furthermore, BKoF was found in all meetings of teaching, MoT was found in two meetings, JCoT was found in two meetings, and ICoT was found in one meeting. It is also revealed that teachers did the following activities in each stage.

\subsection{Building Knowledge of the Field (BKoF)}

This stage should be done in the beginning of the teaching. The analysis shows that this part cropped up in all patterns with which the English teachers started their teaching of the language skills and language components. Uniquely, the activities teachers did in this stage are comparable as presented in the following: greeting the students, checking the attendance, reviewing the previous topic, and introducing the topic to learn.

\subsection{Modelling of the Text (MoT)}

The modelling stage is executed after BKoF. It was revealed from the data, however, that MoT appeared in Patterns 1, 2, and 3. In this context, the majority of the teachers made use of this cycle in the classroom instruction. In teaching listening, speaking, reading, writing and grammar, teachers accomplished the following activities.

In listening, teachers emblematized the classroom teaching as follows: they distributed the listening worksheet and required the students to listen to for comprehension. They played audios or videos in the laptop about the topic two or three times. Sometimes, teachers read the text twice or three times and asked the students to listen to for comprehension. The students listened to the topic/text so that they knew the words, expressions, context, and characters. Students should also answer the given questions about the topic. Teachers then gave feedback and confirmation towards the students' responses.

In speaking, the typical activities teachers undertook in the classroom include the following: they used a laptop and LCD to show the learning materials, examples or videos comprising the models to learn. Sometimes also, they made use of the whiteboard / blackboard to draw or hang the pictures on as a model, or they asked students to see the models of the text in the textbook/worksheet. They then explained or asked students about the topic/text in terms of the communicative purpose, generic structure, and the language features of the text. The students responded to the videos and answered the questions given. The students also had to mention the difficult words found in the text and describe the pictures and their relation to the text being studied. The students repeated the words taken from the text for a better pronunciation. Last, the students got comments or feedback from teachers concerning their responses including the pronunciation. Teachers also re-explained the text being studied for confirmation. In reading, teachers' common classroom activities are presented as follows: they supplied a model of text in the worksheet and or on the screen. They asked students in turn to read a model of text to check the students' pronunciation and modelled how to pronounce the words in the text correctly. They also equipped the text with the information about the communicative purpose and generic structures. In this stage, students were asked to comprehend the text so as to answer the questions related to, for example, the characters, setting, situation, and specific information and to identify unfamiliar words.

In grammar, teachers embodied their teaching in following procedures: they picked up some grammatical models from the text and asked the students to state whether or not they grammatically flawed. Alternatively, teachers asked the students to look at the examples of grammatical sentences in the worksheet. They also asked students to elaborate the characteristics of the tenses used in the text. After that, they explained the forms and uses and gave examples. The examples varied dependent on the text type and topic of grammar. For example, teachers explained simple past when the text was about story or past experience. The students were also assigned to write sentences by using the relevant tenses. Teachers then gave comments and feedback.

\subsection{Joint Construction of the Text (JCoT)}

JCoT is the next stage of teaching using GBA cycles. This phase came up in two patterns: 1 and 3 with the following activities.

In listening, teachers instructed the students to work in groups to listen to the expressions and stories. Here, teachers played audios or videos related to particular expressions. Sometimes, teachers also asked the students to retell funny stories available in the worksheet and the other students in the groups listened to. If no technological aid was used, teachers read the dialog loudly so that the students could hear it well. When listening, students took notes to answer the questions provided by teachers. Occasionally, teachers also let each group re-write a story as heard from the audio. Both teachers and students then discussed the audio text and answers.

In Speaking, teachers asked students in groups to practice speaking by using the provided expressions. Sometimes, teachers also requested students to discuss an issue or a problem. After that, each group reported the results of the discussion or practice speaking in the front. Teachers and other groups gave feedback and comments after each group presentation. In writing, teachers assigned the students (in groups or in pair) to arrange jumbled paragraphs to be a good text or sentences to be a paragraph, wrote a short essay based on the given pictures or a model shown in the video, or to write either a dialog/conversation, functional text (announcement) based the given expressions or models. Teachers then checked the groups' works of simple writing to score and provide some feedback or demanded the groups to present their writing to get feedback from teachers and students.

In reading, teachers asked the students in each group to do reading exercises in the worksheet or read a text loudly and the teacher corrected their pronunciation. In this reading activity, the students analysed the text in terms of the generic structures. Besides, the students also answered the questions, for example, about the thesis, supporting ideas, reasons, type of text, definition of analytical exposition, vocabulary, etc. Teachers also provided feedback and confirmation.

In grammar, the students worked in groups to answer questions related to grammar found in the text. At first, teachers asked the students to find the examples about the use of because, because of, independent and dependent clauses, noun phrases and noun clauses. The students read the examples so that teachers could make sure that they were grammatically correct. Teachers also asked the students to state the reasons about the examples and to do some grammar exercises. The next was that teachers explained the grammar points: definitions, usage, examples, and additional exercises (e.g. completion and making sentences). 


\subsection{Independent Construction of the Text (ICoT)}

This last stage deals with students' independent learning in the classroom. Teachers used it in two patterns: 4 and 5 . The typical teaching activities are described below.

In reading, teachers requested the individual students to read a text in the textbook. Teachers explained the generic structures and difficult words identified from the text. The students were also instructed to answer the questions related to the text. Teachers then gave feedback and confirmation towards students' responses.

In writing, teachers asked the students to write a draft of a narrative text having the components: orientation (main characters, supporting characters, place, and time), beginning of the story, complication, and resolution before they presented the draft to the class. In this process, each student displayed the draft and let teachers and other students give comments. Teachers also checked the components, the organization of ideas, and grammar. Each student then revised the draft based on the feedback. Occasionally, teachers also asked students to use words listed to write sentences on the whiteboard.

In speaking, teachers asked the students to describe some words found in the text and answer the questions related to the communicative purpose, generic structures, and language features. In listening, teachers provided a listening worksheet-listening to a monolog text. They used the laptop to play the audio for three times so that the students could answer the questions (e.g. the topic of the text, the purpose, the facts/arguments, and generic structures) based on what they had heard. The students obtained feedback and confirmation afterwards. Besides, the teachers also equipped the classroom learning with a vocabulary focus-usually the students listed and defined the words taken from the text they did not know.

\section{Discussion and Conclusion}

\subsection{The Teaching of Language Skills and Components}

The current study shows that teachers used the stages of GBA in teaching the language skills and language components which include listening, speaking, reading, writing, and grammar. This finding is in contrast with the previous studies, which mainly made of use of the stages for teaching writing, for instance, Ahn (2012); Carstens (2009); Chen and Su (2012); Emilia (2005); Firkins et al. (2007); Hyon (2001); Kongpetch (2006); Macken-Horarik (2002); Myskow and Gordon (2009); Paltridge (2004); Pujianto et al. (2014); Rothery (1996); Trong (2011); Ueasiriphan and Tangkiengsirisin (2019); Kamal (2019); Yang (2019); Xu (2005); Yigitoglu and Reichelt (2014). They did not cover the other skills such as listening, speaking, reading, and grammar as they, from the outset, were designed to investigate the cycle in one of the language skills only, while the current study deals with a wider scope, namely the use of the cycle in teaching all language skills and components. Besides, the current study uncovers the practice of a cycle containing four stages, whereas the existing previous research employed the cycle with three steps (Firkins et al., 2007; Wu and Dong, 2009; Trong, 2011; Ahn, 2012; Pujianto et al., 2014; Fanani, 2018). Thus, the current study differs from the previous ones as the scopes, settings, participants, and the models of cycle involved were different. In addition to those differences identified above, one interesting phenomenon appeared in the current study is that none of the teachers applied the four stages in teaching even though they were from different backgrounds: schools, age, teaching experience, and involvement in training. The factors that may contribute to this fact include the following. First, they probably did not know the stages of GBA or they knew them just a little although they had been teaching for years. Alternatively, they might be familiar with the terms but did not know what they mean and what to do in each stage. We found that teachers' different backgrounds are not significantly significant in assuring the full application of GBA in teaching.

In terms of schools, for example, teachers were taken from varied state schools under the management of the department of education and culture. The schools where they teach commonly reflect the levels of students' academic and non-academic achievements and teachers' qualification. In connection to the current study, however, teachers who teach in favorite schools do not guarantee their better teaching practices. Conversely, teachers teaching in less favorite ones are those who have poor quality of teaching. In other words, teachers who are placed in favorite schools should be those who are of high quality and carefully selected. They have better knowledge and outstanding teaching practices. Teachers who are put in less favorite schools are the opposite.

Viewed from the teaching experiences, almost all teachers started teaching far before GBA was formally introduced in the curriculum in 2004. This means that they are no longer categorized as novice teachers as they have been teaching for more than five years. In this context, they might have known GBA well including the stages of teaching. Having sufficient experiences is important and assumed to contribute to teachers' productivity and effective teaching and learning (Rice, 2010). However, in the current study teachers with minimum teaching experience are not always parallel with a bad quality of teaching. Conversely, teachers with longer experience of teaching do not guarantee a better teaching. We did not see any differences between teachers having a short year of teaching and a long year of teaching. This phenomenon contradicts with the existing two categories of teachers as suggested by Kraft and Papay (2014). They categorized teachers into two groups: novice teachers with less than five years of experiences and experienced teachers with more than five years of experiences. The existing research has also segregated novice the teachers and experienced teachers under several characteristics. The former tends to be unprepared (Britt, 1997; Jacques, 2000; Ladd, 2000; Savage and Savage, 2010) and have poor skills in the classroom management (Fideler and Haskelhorn, 1999). The latter tends to have abilities to control the classroom interaction and communication with students (Doyle, 1986; Unal and Ünal, 2012) to increase their self-efficacy (Han et al., 2017) and to possess higher flexibility and adaptability in teaching (Kerrins and Cushing, 2000). It is concluded that both categories and their characteristics need to be revisited to accommodate the level of understanding or knowledge about a teaching method (GBA).

Concerning the training, not all teachers were actively involved. The interview results indicate that teachers were not intensively engaged in the workshop and provided with the reliable sources about GBA. They thought that the training was general, unfocused and covered many aspects such as such as policies in education, curriculum, lesson planning, and teaching strategies. Not only that, the training was short in time from 2 to 3 days. They also needed the follow up of the workshops so that they can implement what they obtain from the training to provide better teaching to students. 
The second reason is there is a tendency that the teachers followed the trainers or faculty members' ideas or models regarding what to do and how to do in teaching. In the case of the components of GBA, for example, some trainers consider that the four stages ought to be included in the teaching, while some others have different perceptions. A similar interpretation also happens when they discuss the components of Scientific Approach (Another model of teaching in the Indonesian context) in the Curriculum 2013. Some state that all components are necessarily inserted in the teaching practices, while some others think of two or three components. These differences seem to make the teachers confused on the issue, accordingly. We can say that an example or model provided by a trainer will be the best for them even though it is not yet justified.

Third, there is likelihood that the teachers did not prepare the teaching well. They probably did not make lesson plans which help direct them to what to teach, how to teach, and how to assess the students. Commonly, the teachers elaborate all aspects of teaching, including approach of teaching, method of teaching, and strategy of teaching in the lesson plans. They also explain what they should do (activities) in the pre-activities, whilst activities, and post activities. All things mentioned in the lesson plans should depict the teachers' knowledge on GBA and their skills in teaching.

\subsection{The Application of Stages of GBA in Teaching}

As reflected in the data, all teachers started the teaching with BKoF regardless whether or not they were senior teachers; they joined adequate training; had long experience of teaching; and taught in favorite schools. This implies that whoever the teachers are, wherever and whenever they teach, BKoF is always used as a warming up stage to dig up the students' schemata and connect their prior knowledge with the topic to learn. The successful teaching and meaningful learning can be created when there is a good connection between the students' old and new knowledge (Ausubel and Fitzgerald, 1961).

In this stage, both teachers and students together discuss the background of the text to be learned and share their experiences to deal with it: context of culture, common setting of the text, and benefits of the text (Chaisiri, 2010; Mingsakoon and Srinon, 2018; Hermansson et al., 2019). Yan (2005) and Emilia (2008) also state that BKoF familiarizes students with different texts and their structural features before they start their learning, particularly writing. This stage helps learners in the first stage of cycle (building knowledge of the field) raise their awareness about various texts and their attitudes about writing (Ahn, 2012). Because of these strengths, all models of cycles developed by Murray and Zammit (1992) and Hammond et al. (1992) put BKoF in the beginning to build students' knowledge about the topic to learn.

These features of BKoF, however, were not reflected in the teaching and learning process done by pre-service teachers. A study carried out by Nurlaelawati and Novianti (2017) revealed that most the teachers involved in their study did not apply BKoF in teaching. It happened probably because they had not completed their studies yet, and therefore they did not understand GBA comprehensively. Another possibility is that they probably did not have sufficient experience of implementing the stages of GBA in the classroom practice. So, when they were involved in study, they did not know how to apply the stages in teaching. Very possible, they likely learned more theories and practices during their classes. Different from BKoF, not all teachers applied the modelling stage in teaching. To the best of our observation, it happened as teachers were weak in the planning as indicated by their reluctance to design a lesson plan based on their understanding and interpretation. They preferred to copy the existing model. This phenomenon gets worse as they were busier with administrative things resulting in having no adequate time to make a lesson plan including searching relevant texts students learn. They were not critical in choosing the learning materials that best fit the students either. Here, they looked for a text related to the topic in the absence of scrutiny. In addition, they had a tendency providing one example of text and less details in teaching, as a result, students did not get the intended meaning.

To us, the modelling stage is undeniable in teaching. In this part, teachers can provide students with examples of texts to help students visualize the texts to be learned, hoping that they can internalize the learning materials and produce texts more easily. A study conducted by Pujianto et al. (2014) confirm that the modelling stage is important for students, particularly low achievers, to understand more texts and language skills. Theoretically, MoT is a one step of scaffolding which needs to be included in the teaching and learning process. In Halliday's theory of Systemic Functional Linguistics, scaffolding, as a means of helping learners to achieve the goal of their learning, is reflected in the idea of explicit instruction done by teachers about language features of texts. The types of scaffolding can be in two forms: providing contents of students learning and roles or activities to be undertaken by students in the classroom (Kollar et al., 2006). A study conducted by Kerfoot and Van Heerden (2015) indicate that the scaffolding of genre-based approach considerably impacts students' learning access of language of the school subjects. In addition, teachers also incorporated joint working (JCOT) in the teaching and learning process as identified in the patterns 1 and 3. As the most critical part of the cycle, this third phase requires teachers and students to do collaboration to yield a text. In fact, not all teachers in the present study apply it in teaching. It implies that some teachers are sure with the advantages of this stage in the instruction and some others are the opposite. Those who believe in this collaboration advocate the results of studies informing that the joint construction of text aids students in developing their writings (Dreyfus et al., 2011; Martin and Rose, 2012; Caplan and Farling, 2016). Those who are doubtful about the joint writing also supports the finding of a quasiexperimental study undertaken by Hermansson et al. (2019). They approved that joint construction had no considerable effect on the students' quality of narrative writing as well as the length of their writings. Thus, it is concluded that the issue about the importance of joint construction of the text in the classroom instruction is not conclusive yet. Regardless of the different findings, we believe that joint construction is a form of collaboration which is pivotal in the classroom context. Collaboration allows teachers and students to create dialogic interaction and communication to get problems solved, prepares students before they work independently, and enables students to become readier and more confident to complete the tasks. Webb et al. (2008) state collaboration enables students to learn with others. Pearlman (2010) strengthens that collaboration is one of the $21^{\text {st }}$ century skills needed by students to be able to compete in the global market. Similarly, Foltos (2015) says that collaboration is 
crucial to support and build successful school programs. Therefore, learning and teaching will not take place without collaboration.

The last stage of GBA is Independent Construction of the Text where students work individually and independently to complete the given tasks. Similar to the Joint Construction, not all teachers carried out this step in teaching. It is identified that independent working was done in two ways: inside the class and outside the class as homework. All of them depended on the availability of time. If teachers had time to complete the task, they required students to finish it in the classroom, but if the teachers ran out of time, they asked students to complete the task at home as homework. In the current research, we found that this stage was identified when teachers focused on reading, writing, speaking and listening.

The independent construction puts an emphasis on the individuals strong autonomy in learning and producing a text. They become readier and more self-determining after they get aids and work together with their peers or teachers to complete the tasks. Nosratinia and Zaker (2014) state that learning autonomy enables learners to achieve their learning goals as they know what to do, check the progress, and evaluate the learning results (Benson, 2013). A plenty of research suggests that learning autonomy contributes to students' language development as well as their language learning (Smith and Craig, 2013; Fahim and Zaker, 2014; Lee, 2014; Bekleyen and Selimoğlu, 2016). It is summarized that learning and producing a text independently is a part of students-centered learning which is crucial in the classroom.

It is concluded that the EFL teachers have practiced the cycle in teaching language skills and components under the following patterns: BKoF-MoT-JCoT; BKoF-JCoT; BKoF-MoT; BKoF-MoT-ICoT; and BKoF-ICoT even though none of them applied the four stages as suggested. In particular, all teachers build the background of the text to be learned in the beginning of the lesson, yet not all of teachers provide models and include joint construction and independent construction in teaching. In addition, teachers who teach in favorite schools, possess more teaching experience, get more involvement in training, and are older in age do not guarantee that they understand and apply the stages of GBA in teaching better than those who do not.

It is suggested that EFL teachers be more intensively involved in the more focused training whatever their backgrounds are. All EFL teachers need to be given the same opportunities to join the training so that they have knowledge and abilities to implement it in the classroom. The training should also be conducted in sufficient amount of time, with a specific topic on GBA, theoretically and practically balanced, and hand-on follow up activities. These aspects are important in the context of making teachers become prepared and ready to create a better teaching.

\section{References}

Ahn, H., 2012. Teaching writing skills based on a genre approach to L2 primary school students: An action research. English Language Teaching, 5(2): 2-16.Available at: https://doi.org/10.5539/elt.v5n2p2.

Ausubel, D.P. and D. Fitzgerald, 1961. Chapter v: Meaningful learning and retention: Intrapersonal cognitive variables. Review of Educational Research, 3 1(5): 500-5 10.Available at: https://doi.org/10.2307/1168901.

Bekleyen, N. and F. Selimoğlu, 2016. Learner behaviors and perceptions of autonomous language learning. The Electronic Journal for English as a Second Language, 20(3): 1-20.

Benson, P., 2013. Drifting in and out of view: Autonomy and the social individual. In P. Benson \& L. Cooker (Eds.), The applied linguistic individual: Sociocultural approaches to identity, agency and autonomy. Sheffield, UK: Equinox. pp: 75-89.

Britt, P.M., 1997. Perceptions of beginning teachers: Novice teachers reflect upon their beginning experiences. Paper Presented at the Annual Meeting of the Mid-South Educational Research Association, Memphis, TN.

Callaghan, M. and P. Knapp, 1989. The discussion genre. Sydney: Met East DSP (Language and Social Power ProJect).

Caplan, N.A. and M. Farling, 2016. A dozen heads are better than one: Collaborative writing in genre-based pedagogy. TESOL Journal, 8(3): $564-581$.

Carstens, A., 2009. The effectiveness of genre-based approaches in teaching academic writing: Subject specific versus cross-disciplinary emphases. Unpublished Doctoral Dissertation. Sotho: University of Pretoria.

Chaisiri, T., 2010. Implementing a genre pedagogy to the teaching of writing in a university context in Thailand. Language Education in Asia, 1(1): 181-199.Available at: https://doi.org/10.5746/leia/10/v 1/a 16/chaisiri.

Chen, Y.-S. and S.-W. Su, 2012. A genre-based approach to teaching EFL summary writing. ELT Journal, 66(2): 184-192.Available at: https://doi.org/10.1093/elt/ccro61.

De Oliveira, L.C. and S.-W. Lan, 2014. Writing science in an upper elementary classroom: A genre-based approach to teaching English language learners. Journal of Second Language Writing, 25: 23-39.Available at: https://doi.org/10.1016/j.jslw.2014.05.001.

Derewianka, B., 2012. Knowledge about language in the Australian curriculum: English. Australian Journal of Language and Literacy, $35(1)$ : $127-146$.

Doyle, W., 1986. Classroom organization and management. In M. C. Wittrock (Ed.), Handbook of research on teaching (3rd Ed.). New York: Macmillan.

Dreyfus, S.J., L. Macnaught and S. Humphrey, 2011. Understanding joint construction in the tertiary context. Linguistics and the Human Sciences, 4(2): 135-160.

Emilia, E., 2005. A critical genre-based approach to teaching academic writing in a tertiary EFL context in Indonesia. A Ph.D. Thesis Submitted to the University of Melbourne.

Emilia, E., 2008. Functional systemic linguistics and reading to learn programs in teaching reading and writing. A Paper Presented in the First Conference on Applied Linguistics.

Emilia, E., 2011. Genre-based approach in teaching English: Instructions for teachers. Bandung: Rizqi Press.

Emilia, E. and F.A. Hamied, 2015. Systemic functional linguistic genre pedagogy (SFL GP) in a tertiary EFL writing context in Indonesia. TEFLIN Journal, 26(2): 155-182.Available at: https://doi.org/10.15639/teflinjournal.v26i2/155-182.

Fahim, M. and A. Zaker, 2014. EFL learners' creativity and critical thinking: Are they associated? Humanising Language Teaching, 16(3).

Fanani, A., 2018. The implementation of genre-based approach in teaching writing. Smart Journal, 4(2): 132- 141.

Fideler, E. and D. Haskelhorn, 1999. Learning the ropes: Urban teacher induction programs and practices in the United States. Belmont, MA: Recruiting New Teachers.

Firkins, A., G. Forey and S. Sengupta, 2007. Teaching writing to low proficiency EFL students. ELT Journal, 61(4): 341-352.Available at: https://doi.org/10.1093/elt/ccm052.

Foltos, L., 2015. Principals boost coaching's impact. The Learning Professional, 36(1): 48-51.

Graves, K. and S. Garton, 2017. An analysis of three curriculum approaches to teaching English in public-sector schools. Language Teaching, 50(4): 441-482.Available at: https://doi.org/10.1017/s0261444817000155.

Hammond, J., A. Burns, H. Joyce, D. Brosnan and L. Gerot, 1992. English for special purposes: A handbook for teachers of adult literacy. Sydney: NCELTR, Macquarie University Press.

Han, I., W.S. Shin and Y. Ko, 2017. The effect of student teaching experience and teacher beliefs on pre-service teachers' self-efficacy and intention to use technology in teaching. Teachers and Teaching, 23(7): 829-842.Available at: https://doi.org/10.1080/13540602.2017.1322057. 
Hermansson, C., B. Jonsson, M. Levlin, A. Lindhé, B. Lundgren and A.N. Shaswar, 2019. The (non)effect of joint construction in a genrebased approach to teaching writing. The Journal of Educational Research, 112(4): 483-494

Hyland, K., 2007. Genre pedagogy: Language, literacy and L2 writing instruction. Journal of Second Language Writing, 16(3): 148-164.

Hyon, S., 2001. Long-term effects of genre-based instruction: A follow-up study of an EAP reading course. English for Specific Purposes, 20: 417-438.Available at: https://doi.org/10.1016/s0889-4906(01)00019-9.

Jacques, K., 2000. Solicitous tenderness: Discipline and responsibility in the classroom. In H. Cooper and R. Hyland (Eds.) Children's perceptions of learning with trainee teachers. London: Routledge. pp: 166-177.

Kamal, S.M., 2019. Developing EFL learners vocabulary by reading English comprehension in EFL classroom. International Journal of English Language and Literature Studies, 8(1): 28-35.Available at: https://doi.org/10.18488/journal.23.2019.81.28.35.

Kerfoot, C. and M. Van Heerden, 2015. Testing the waters: Exploring the teaching of genres in a Cape Flats Primary School in South Africa. Language and Education, 29(3): 235-255.Available at: https://doi.org/10.1080/09500782.2014.994526.

Kerrins, J.A. and K.S. Cushing, 2000. Taking a second look: Expert and novice differences when observing the same classroom teaching segment a second time. Journal of Personnel Evaluation in Education, 14(1): 5-24.

Kollar, I., F. Fischer and F.W. Hesse, 2006. Collaboration scripts-a conceptual analysis. Educational Psychology Review, 18(2): 159185.Available at: https://doi.org/10.1007/s 10648-006-9007-2.

Kongpetch, S., 2006. Using a genre-based approach to teach writing to Thai students: A case study. Prospect, 12(2): 3- 32.

Kraft, M.A. and J.P. Papay, 2014. Can professional environments in schools promote teacher development? Explaining heterogeneity in returns to teaching experience. Educational Evaluation and Policy Analysis, 36(4): 476-500.Available at: https://doi.org/10.3102/0162373713519496.

Ladd, K., 2000. A comparison of teacher education programs and graduate's perceptions of experiences. Dissertation Abstracts International, $61(12 \mathrm{~A}): 4695$.

Lee, L., 2014. Digital news stories: Building language learners' content knowledge and speaking skills. Foreign Language Annals, 47(2): $338-356$.

Lorenzo, F., 2013. Genre-based curricula: Multilingual academic literacy in content and language integrated learning. International Journal of Bilingual Education and Bilingualism, 16(3): 375-388.Available at: https://doi.org/10.1080/13670050.2013.777391.

Macken-Horarik, M., 2002. Something to shoot for: A systemic functional approach to teaching genre in secondary school science. In A. M. Johns (Ed.), Genre in the classroom: Multiple Perspectives. Mahwah, US: Lawrence Erlbaum Associates. pp: 17-42.

Martin, J. and D. Rose, 2012. Genres and texts: Living in the real world. Indonesian Journal of SFL, 1(1): 1-21.

Mbau, A.T. and B. Sugeng, 2019. Critical Literacy for ELT in Indonesia: What EFL Teachers should be Aware of. Journal of English Language Teaching and Linguistics, 4(2): 143-156.Available at: https://doi.org/10.2 1462/jeltl.v4i2.255.

Mingsakoon, P. and U. Srinon, 2018. Development of secondary school students' generic structure execution in personal experience recount writing texts through SFL genre-based approach. Advances in Language and Literary Studies, 9(6): 112-119.Available at: https://doi.org/10.7575/aiac.alls.v.9n.6p.112.

Moore, J. and M. Schleppegrell, 2014. Using a functional linguistics metalanguage to support academic language development in the English Language Arts. Linguistics and Education, 26: 92-105.Available at: https://doi.org/10.1016/j.linged.2014.01.002.

Murray, N. and K. Zammit, 1992. The action pack animals: Teaching factual writing K-6. Sydney: Metropolitan East Disadvantaged Schools Program.

Myskow, G. and K. Gordon, 2009. A focus on purpose: Using a genre approach in an EFL writing class. ELT Journal, 64(3): 283-292.

Nosratinia, M. and A. Zaker, 2014. Metacognitive attributes and liberated progress: The association among second language learners' critical thinking, creativity, and autonomy. SAGE Open, 4(3): 1-10.

Nurlaelawati, I. and N. Novianti, 2017. The practice of genre-Based pedagogy in Indonesian schools: A case of Preservice teachers in Bandung, West Java Province. Indonesian Journal of Applied Linguistics, 7(1): 160-166.Available at: https://doi.org/10.17509/ijal.v7i1.6869.

Paltridge, B., 2004. Academic writing. Language Teaching, 37(2): 87-105.Available at: https://doi.org/10.1017/S0261444804002216.

Pearlman, B., 2010. Designing new learning environment to support 21 st century skills. 21 st century skills: Rethinking how students learn. Bloomington, IN: Solution Tree Press.

Pujianto, D., E. Emilia and S.M. Ihrom, 2014. A process-genre approach to teaching writing report text to senior high school students. Indonesian Journal of Applied Linguistics, 4(1): 99-110.Available at: https://doi.org/10.17509/ijal.v4i 1.603.

Rice, J., 2010. The impact of teacher experience: Examining the evidence and implications for policy. Research brief for the center for longitudinal data in education research. Washington DC: The Urban Institute.

Rothery, J., 1996. Making changes: Developing an educational linguistics. In R. Hasan \& G. Williams (Eds.), Literacy in Society. London: Longman.

Savage, T.V. and M.K. Savage, 2010. Successful classroom management and discipline: Teaching self-control and responsibility. Los Angeles: Sage Publications, Inc.

Smith, K. and H. Craig, 2013. Enhancing the autonomous use of CALL: A new curriculum model in EFL. CALICO Journal, $30(2)$ : $252-278$.

Trong, L., 2011. Teaching writing through genre-based approach. Theory and Practice in Language Studies, 11(11): 1471-1478.Available at: https://doi.org/10.4304/tpls.1.11.1471-1478.

Ueasiriphan, T. and S. Tangkiengsirisin, 2019. The effects of genre-based teaching on enhancement of Thai engineers' technical writing ability. International Journal of Instruction, 12(2): 723-738.Available at: https://doi.org/10.29333/iji.2019.12246a.

Unal, Z. and A. Ünal, 2012. The impact of years of teaching experience on the classroom management approaches of elementary school teachers. International Journal of Instruction, 5(2): 41-53.

Webb, N.M., M.L. Franke, M. Ing, A. Chan, T. De, D. Freund and D. Battey, 2008. The role of teacher instructional practices in student collaboration. Contemporary Educational Psychology, 33(3): 360-381.

Wu, Q.Z., 2016. Engaging students in academic literacies: Genre-based pedagogy for k-5 classrooms. Journal of Second Language Writing, 31: 9-10.Available at: http://dx.doi.org/10.1016/j.jslw.2015.12.003.

Wu, Y. and H. Dong, 2009. Applying SF-based genre approaches to English writing class. International Education Studies, 2(3): 7781.Available at: https://doi.org/10.5539/ies.v2n3p77.

Xu, L.-L., 2005. A genre-based approach to the writing of the introduction section of an ESL/EFL academic paper. Sino-US English Teaching, 2(11): 22-26.

Yan, G., 2005. A process genre model for teaching writing. English Teaching Forum, 43(3): 18-26.

Yang, P.L., 2019. Investigating the impact of English picture books on EFL learners'anxiety in Taiwan. Humanities and Social Sciences Letters, 7(2): 56-63.Available at: https://doi.org/10.18488/journal.73.2019.72.56.63.

Yigitoglu, N. and M. Reichelt, 2014. Using a genre-based approach for writing instruction in a less-commonly-taught language. Language Awareness, 23(3): 187-202.Available at: https://doi.org/10.1080/09658416.2012.742906. 